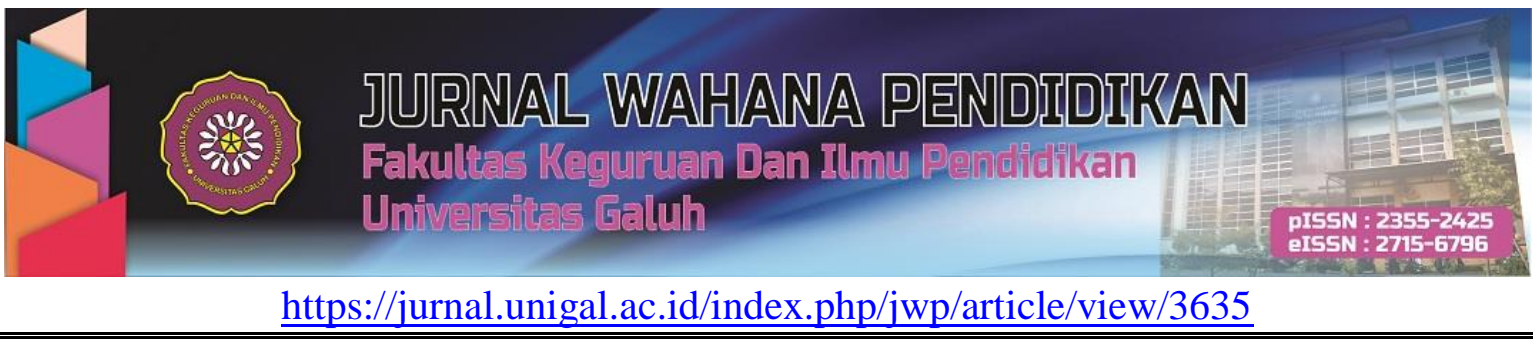

\title{
PENGGUNAAN METODE RESITASI UNTUK MENINGKATKAN HASIL BELAJAR SISWA PADA PEMBELAJARAN IPS TERPADU TENTANG LETAK GEOGRAFIS DAN KOORDINAT NEGARA ASEAN (Penelitian Tindakan Kelas di Kelas VIII-G SMPN 6 Tasikmalaya)
}

\author{
Eti Rumiati ${ }^{1}$ \\ 1,2SMPN 6 Tasikmalaya, Jl. Cilembang No.114, Tasikmalaya, Indonesia \\ Email: 1etimutakin@gmail.com,
}

\begin{abstract}
The purpose of this study was to determine the use of the recitation method to improve student learning outcomes in social studies learning about Geographical Location and ASEAN Country Coordinates in Class VIII-G of SMPN 6 Tasikmalaya. The research method is Classroom Action Research (PTK). The results of the data analysis showed that the first action learning plan got an average score of 3,35 or $83,75 \%$. Meanwhile, the second action learning plan obtained an average score of 4,00 or $100 \%$. The results of data analysis also showed that the average score of teacher activity in the first action was 3,06 or $76,5 \%$. The second act received an average score of 3,50 or $87,5 \%$. For student activity in the second action the students got an average score of 3,12 or $78 \%$. In the second action got an average score of 3,62 or $90,55 \%$. The results of student learning in each cycle obtained data that in the first action the average value was 79 , in the second action it was 84 . This means that social studies learning through the recitation method, in addition to influencing the planning and implementation of learning, also has an effect on improving learning outcomes. students.
\end{abstract}

Keywords: recitation method, student learning outcomes

\begin{abstract}
ABSTRAK
Tujuan penelitian ini adalah untuk mengetahui penggunaan metode resitasi untuk meningkatkan hasil belajar siswa pada pembelajaran IPS tentang Letak Geografis dan Koordinat Negara ASEAN di Kelas VIII-G SMPN 6 Tasikmalaya. Metode penelitian adalah Penelitian Tindakan Kelas (PTK). Hasil analisis data menunjukkan bahwa Rencana Pelaksanaan Pembelajaran tindakan pertama mendapat skor rata-rata 3,35 atau 83,75\%. Sedangkan rencana pembelajaran tindakan kedua memperolah skor rata-rata 4,00 atau $100 \%$. Hasil analisis data juga menunjukkan bahwa skor rata-rata aktivitas guru pada tindakan pertama adalah 3,06 atau 76,5\%. Tindakan kedua mendapat skor rata-rata 3,50 atau 87,5\%. Untuk aktivitas siswa pada tindakan kedua siswa mendapat skor rata-rata 3,12 atau 78\%. Pada Tindakan kedua mendapat skor rata-rata 3,62 atau $90,55 \%$. Hasil belajar siswa pada setiap siklus diperoleh data bahwa pada tindakan pertama nilai rata-rata sebesar 79, pada tindakan kedua sebesar 84 . Hal ini dapat diartikan bahwa pembelajaran IPS melalui metode resitasi, selain berpengaruh terhadap rencana dan pelaksanaan pembelajaran, juga berpengaruh terhadap peningkatkan hasil belajar siswa.
\end{abstract}

Kata kunci: metode resitasi, hasil belajar siswa

Cara sitasi: Rumiati, E. (2020). Penggunaan Metode Resitasi Untuk Meningkatkan Hasil Belajar Siswa Pada Pembelajaran IPS Terpadu tentang Letak Geografis dan Koordinat Negara ASEAN (Penelitian Tindakan Kelas Di Kelas VIII-G SMPN 6 Tasikmalaya). Jurnal Wahana Pendidikan, 7 (2), 211-222. 


\section{PENDAHULUAN}

Salah satu permasalahan yang dihadapi pendidikan di Indonesia saat ini adalah berkenaan dengan kegiatan belajar mengajar yang dipandang masih belum efektif. Pendekatan dan metode yang digunakan kurang bervariasi, biasanya mengandalkan dalam bentuk ceramah. Dalam berinteraksi dengan siswa, posisi guru sangat mendominasi, sementara siswa berada dalam keadaan sebagai pendengar. Konsep pembelajaran tersebut tidak lagi relevan dengan tuntutan dan tantangan pendidikan saat ini.

Pelaksanaan pengajaran selayaknya berpegang pada apa yang tertuang dalam perencanaan. Selain itu, dalam rangka meningkatkan keaktifan siswa dalam proses pembelajaran harus ditunjang dengan alat bantu atau media pembelajaran yang sesuai dengan pokok bahasan yang diajarkan. Selain siswa sebagai pelaku utama dalam proses pembelajaran, guru dituntut memiliki dan menguasai keterampilan mengajar dalam proses pembelajaran.

Berdasarkan pengalaman nyata dan hasil refleksi dari penulis, ada satu kendala yang penulis temukan yaitu siswa kurang paham dalam pembelajaran IPS tentang materi Letak Geografis dan Koordinat Negara ASEAN. Berdasarkan hasil belajar siswa Kelas VIII-G SMPN 6 Tasikmalaya menunjukan dari jumlah siswa 31 orang memperoleh nilai rata-rata sebesar 74. Artinya taraf hasil belajar siswa kurang dari KKM yaitu sebesar 80 . Hal ini dikarenakan ketersediaan media kurang memadai sehingga berakibat hasil belajar siswa pun kurang bagus. Penyebab kurang berhasilnya proses pembelajaran adalah kurangnya penugasan dan latihan. Guru belum mampu memberdayakan seluruh potensi yang ada pada diri siswa sehingga sebagian siswa belum mampu mencapai kompetensi individual yang diharapkan untuk mengikuti pembelajaran.

Tujuan pembelajaran di Sekolah yaitu "Meletakan dasar kecerdasan, pengetahuan, kepribadian, akhlak mulia, serta keterampilan untuk hidup mandiri dan mengikuti pendidikan lebih lanjut“ (BSNP, 2006). Dalam rangka mewujudkan tujuan pembelajaran di Sekolah, salah satu upaya yang harus dilakukan guru yaitu menyempurnakan dan meningkatkan kinerja sebagai pendidik yang profesional, dalam artian guru harus mampu mengidentifikasi hal-hal yang dapat menunjang pada proses kegiatan pembelajaran. Perencanaan, pelaksanaan, saran dan sumber belajar, dan evaluasi merupakan hal yang sangat penting untuk kelancaran pelaksanaan pembelajar. "Guna mencapai tujuan tersebut dapat dikemukakan beberapa media/strategi dan teknik mengajar yang sekaligus dapat memandu materi pengajaran dalam penggunaan metode mengajar yang dimaksud" (Wahab, 2007). Dengan demikian, untuk mengimplementasikan proses belajar mengajar mata pelajaran ekonomi, berdasarkan pengalaman penulis dalam kegiatan proses belajar mengajar di Kelas VIII-G SMPN 6 Tasikmalaya, menyangkut metode pembelajaran, penggunaan/pemanfaatan metode pembelajaran pada mata pelajaran IPS masih belum tepat.

Dalam proses pembelajaran IPS di SMP, penyajian metode pembelajaran seorang guru dituntut agar bervariatif dan inovatif guna merangsang motivasi siswa untuk belajar dan mencegah siswa agar tidak jenuh dalam belajar, sehingga siswa siap untuk mengikuti proses belajar mengajar yang menyenangkan bagi siswa agar tujuan dari pembelajaran dapat dicapai sesuai dengan yang diharapkan. Adapun salah satu metode yang diterapkan dalam melibatkan siswa secara aktif, guna menunjang kelancaran proses belajar mengajar adalah menggunakan metode resitasi. Menurut Sudjana (1989), bahwa : "Metode resitasi diharapkan mampu memancing keaktifan siswa dalam proses belajarn mengajar". Hal ini disebabkan karena siswa dituntut untuk menyelesaikan tugas yang diberikan guru dan harus dipertanggungjawabkan. Dalam keberhasilan proses belajar mengajar disamping tugas guru, maka siswa turut memegang peranan yang menentukan dalam pencapaian tujuan pendidikan. Sebab bagaimapun baiknya penyajian guru terhadap materi pelajaran, akan tetapi siswa tidak mempunyai perhatian dalam hal belajar maka apa yang diharapkan sukar tercapai.

Menurut Slameto (1991) sebagai berikut : 
Agar siswa berhasil dalam belajarnya, perlulah mengerjakan tugas dengan sebaik-baiknya. Tugas itu mencakup mengerjakan PR, menjawab soal latihan buatan sendiri, soal dalam buku pegangan, tes/ualangan harian, ulangan umum dan ujian.

Pembelajaran dengan metode mengajar yang sesuai dengan materi yang diajarkan akan meningkatkan motivasi belajar siswa. Menurut Harmawati (1993) bahwa : "Pemberian tugas pada setiap pertemuan mempengaruhi hasil belajar siswa". Dengan demikian tugas setiap pertemuan menyebabkan siswa termotivasi dalam belajar, disamping itu siswa lebih aktif dalam kegiatan belajar mengajar.

Metode resitasi merupakan suatu bentuk pekerjaan yang harus diselesaikan. Pemberian tugas sebagai suatu metode mengajar merupakan suatu pemberian pekerjaan oleh guru kepada siswa untuk mencapai tujuan pengajaran tertentu. Dengan pemberian tugas tersebut siswa belajar dengan mengerjakan tugas. Dalam melaksanakan kegiatan belajar, siswa diharapkan memperoleh suatu hasil bentuk perubahan tingkah laku tertentu sesuai dengan tujuan yang telah ditetapkan. Tahap terakhir pemberian tugas ini adalah resitasi yang berarti melaporkan atau menyajikan kembali tugas yang telah dikerjakan atau dipelajari. Jadi metode pemberian tugas belajar dan resitasi atau biasanya disingkat metode resitasi merupakan suatu metode mengajar dimana guru membebankan bentuk tugas, kemudian siswa harus mempertanggungjawabkan hasil tugas tersebut.

Alipandie (2004) mengemukakan bahwa :

Metode resitasi adalah cara untuk mengajar yang dilakukan dengan jalan memberi tugas

khusus kepada siswa untuk mengerjakan sesuatu di luar jam pelajaran. Pelaksanaannya bisa dirumah, diperpustakaan, dilaboratorium, dan hasilnya dipertanggungjawabkan.

Sedangkan Slameto (2001) mengemukakan "Metode resitasi adalah cara penyampaian bahan pelajaran dengan memberikan tugas kepada siswa untuk dikerjakan diluar jadwal sekolah dalam rentangan waktu tertentu dan hasilnya harus dipertanggungjawabkan kepada guru". Metode resitasi merupakan salah satu pilihan metode mengajar seorang guru, dimana guru memberikan sejumlah item tes kepada siswanya untuk dikerjakan di luar jam pelajaran. Pemberian item tes ini biasanya dilakukan pada setiap kegiatan belajar mengajar di kelas, pada akhir setiap pertemuan atau akhir pertemuan di kelas. Rostiyah (2001) menyatakan bahwa guru perlu memberikan tugas-tugas diluar jam pelajaran. Seperti pemberian tugas-tugas berupa PR mempunyai pengaruh yang positif terhadap peningkatan hasil belajar .

Selanjutnya, metode resitasi ini dianggap efektif bila hal-hal berikut ini dapat dilaksanakan yaitu "merumuskan tujuan khusus yang hendak dicapai, tugas yang diberikan harus jelas, waktu yang disediakan untuk menyelasaikan tugas harus cukup" (Alipandie, 2001). Sudirman (2002) menyatakan langkah-langkah yang ditempuh dalam pendekatan pelaksanaan metode resitasi yaitu : tugas yang diberikan harus jelas, tempat dan lama waktu penyelesaian tugas harus jelas, tugas yang diberikan terlebih dahulu dijelaskan/diberikan petunjuk yang jelas, agar siswa yang belum mampu memahami tugas itu berupaya untuk menyelesaikannya, guru harus memberikan bimbingan utamanya kepada siswa yang mengalami kesulitan belajar atau salah arah dalam mengerjakan tugas, dan Memberi dorongan terutama bagi siswa yang lambat atau kurang bergairah mengerjakan tugas.

Metode resitasi mempunyai kelebihan dalam proses belajar mengajar. Adapun kelebihan metode resitasi adalah "anak menjadi terbiasa mengisi waktu luangnya, memupuk rasa tanggung jawab, melatih anak berpikir kritis, tekun, giat dan rajin" (Alipandie, 2001).

IImu Pengetahuan Sosial (IPS) merupakan mata pelajaran yang mengajarkan pada siswa SMP/MTs, agar siswa mengenal fenomena-fenomena sosial, mulai dari yang dekat dengan lingkungannya sampai dengan fenomena dunia. Pada kenyataannya kehidupan itu tidak dipisahkan antara satu dengan yang lainnya. Setiap manusia akan berdampak pada yang lain dan pada lingkungannya. Ruang lingkup pembelajaran IImu Pengetahuan Sosial di SMP menurut Kurikulum (BSNP, 2006) meliputi aspek-aspek: manusia, tempat dan lingkungan, waktu, berkelanjutan dan perubahan , sistem, sosial dan budaya, dan perilaku ekonomi dan kesejahteraan. 
Di masa yang akan datang peserta didik akan menghadapi tantangan berat, karena kehidupan masyarakat selalu mengalami perubahan setiap saat. Oleh karena itu, mata pelajaran IPS dirancang untuk mengembangkan pengetahuan pemahaman dan kemampuan analisis terhadap kondisi sosial masyarakat dalam memasuki kehidupan bermasyarakat yang dinamis. "Tujuan IImu Pengetahuan Sosial (IPS) adalah untuk mengembangkan pengetahuan dan keterampilan dasar yang berguna bagi dirinya dalam kehidupan sehari-hari" (BSNP, 2006).

Dalam keseluruhan proses pendidikan di sekolah, kegiatan belajar merupakan kegiatan yang paling pokok. Ini berarti berhasil tidaknya pencapaian tujuan pendidikan banyak bergantung kepada bagaimana proses belajar yang dialami oleh siswa sebagai anak didik. Menurut Ahmadi (2004), "Belajar merupakan suatu kegiatan menghafal sejumlah fakta-fakta. Sejalan dengan pendapat ini, maka seorang yang telah belajar akan ditandai dengan banyaknya fakta-fakta yang dapat dihafalkan". Berdasarkan hal tersebut, hasil belajar adalah suatu nilai yang menunjukkan hasil dalam belajar yang dicapai menurut kemampuan siswa dalam mengerjakan suatu tugas pada saat tertentu pula. Terdapat pengertian lain tentang hasil belajar yakni kemampuan yang dapat dinyatakan oleh siswa setelah mempelajari seluruh pokok bahasan. Kemampuan-kemapuan tersebut meliputi : menggambarkan, menyebutkan, melaksanakan, menghitung atau segala yang mengacu pada tujuan instruksional khusus yang telah dirancang sebelumnya atau hasil akhir yang dicapai sebaik-baiknya dalam jangka waktu tertentu.

Sedangkan Rusyan (1989), mengemukakan bahwa kunci pokok untuk memperoleh ukuran dan data hasil belajar siswa sebagaimana yang terurai di atas adalah Pengetahuan garis-garis besar indikator (penunjuk adanya prestasi tertentu) dikaitkan dengan jenis prestasi yang hendak diungkapkan atau diukur. Pada tahap perencanaan guru perlu merumuskan terlebih dahulu topik, materi, atau masalah apa yang akan dibahas atau disajikan. Selanjutnya perlu juga dirumuskan jenis layanan atau kegiatan pendukung apa yang akan diselenggarakan, siapa yang menjadi sasaran layanan, metode apa yang akan digunakan, kapan kegiatan tersebut akan dilakukan, serta siapa yang akan menyelenggarakan atau pihak-pihak mana yang akan dilibatkan.

Berdasarkan permasalahan yang telah diuraikan maka penulis tertarik untuk melakukan penelitian dengan tujuan untuk mengetahui penggunaan metode resitasi untuk meningkatkan hasil belajar siswa pada pembelajaran IPS tentang Letak Geografis dan Koordinat Negara ASEAN di Kelas VIII-G SMPN 6 Tasikmalaya.

\section{METODE PENELITIAN}

Subjek dalam penelitian adalah siswa kelas VIII-G SMPN 6 Tasikmalaya. Penelitian ini adalah Penelitian Tindakan Kelas (PTK). Skema alur tindakan penelitian yang diadopsi dari Kasbolah (1999) tercantum pada Gambar 1.

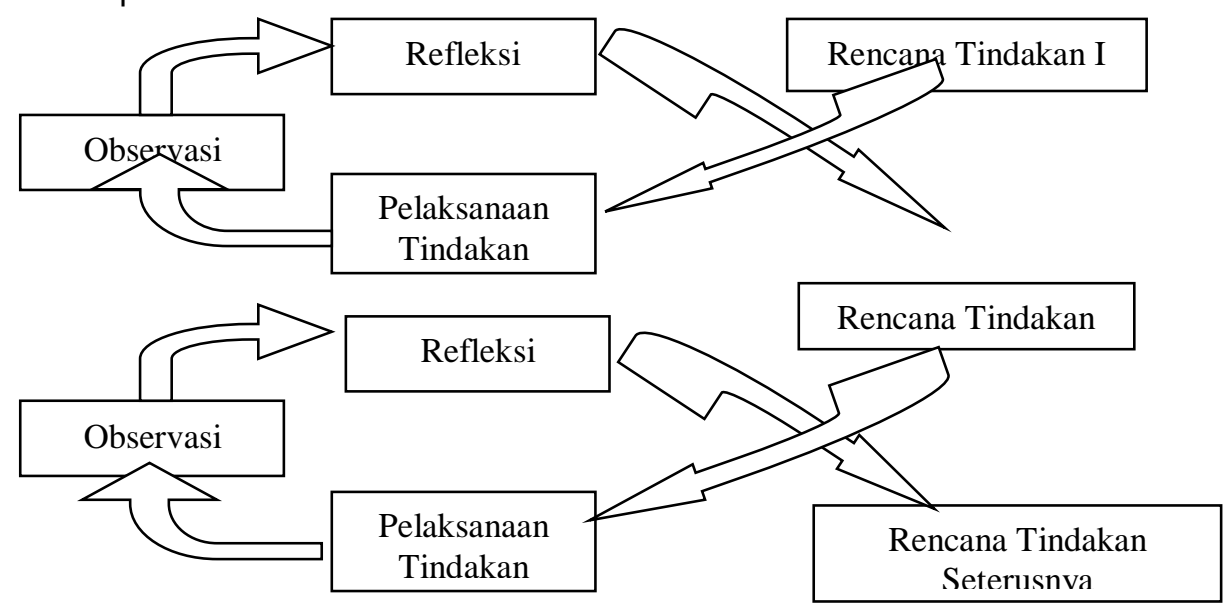

Gambar 1. Spiral Penelitian Tindakan Kelas 
Penelitian Tindakan Kelas yang terdiri dari empat tahapan dasar saling terkait dan berkesinambungan, yaitu : Perencanaan tindakan (Planning), Pelaksanaan tindakan (Acting), Pengamatan tindakan (Observasi), dan Refleksi terhadap tindakan (Reflecting). Teknik dan instrumen pengumpulan data selama pelaksanaan Penelitian Tindakan Kelas adalah sebagai berikut : observasi, tes. Analisis data meliputi teknik coding, teknik trigulasi dan teknik saturasi.

\section{HASIL DAN PEMBAHASAN \\ Orientasi dan Identifikasi Masalah \\ Keadaan Kelas}

Kelas yang digunakan dalam penelitian ini adalah kelas VIII-G Semester I Tahun Ajaran 2017/2018. SMPN 6 Tasikmalaya sangat baik, baik sarana, maupun prasarananya, dengan jumlah siswa sebanyak 31 orang, terdiri dari 15 orang siswa laki-laki dan 16 orang siswa perempuan. Keadaan ekonomi orang tua siswa heterogen, terdiri dari keluarga Pegawai Negeri, pedagang, petani dan buruh. Adapun prosentase siswa tersebut dapat dilihat pada Table 1.

Tabel 1.

Prosentase Jenis Kelamin Siswa Kelas VIII-G

Semester I Tahun Ajaran 2017/2018

SMPN 6 Tasikmalaya

\begin{tabular}{llll}
\hline No & Jenis Kelamin & Jumlah & Prosentase (\%) \\
\hline 1. & Laki-laki & 15 & 48 \\
2. & Perempuan & 16 & 52 \\
Jumlah & 31 & 100 \\
\hline
\end{tabular}

Dari data di atas yang dinyatakan dengan prosentase, jenis kelamin siswa laki-laki $48 \%$ dan perempuan $52 \%$.

\section{Aktivitas Siswa}

Selama pembelajaran berlangsung aktivitas siswa sangat kurang mendapatkan konsep terutama dalam pembelajaran IPS tentang Letak Geografis dan Koordinat Negara ASEAN melalui metode resitasi. Keterampilan ilmiah siswa secara garis besar berkadar cukup kecuali dalam hal memahami metode pembelajaran sudah berkadar baik. Sedangkan untuk sikap ilmiah siswa secara garis besar berkadar cukup, kecuali dalam hal berani bertanya dan berani mengeluarkan pendapat masih berkadar kurang.

\section{Hasil Belajar Awal Siswa}

Minat belajar siswa sewaktu observer mengamati pembelajaran IPS sangat kurang. Salah satu penyebab karena dalam pelaksanaan pembelajaran IPS guru tidak memiliki kemauan mengemas metode pembelajaran yang digunakan, sehingga siswa beranggapan bahwa pembelajaran IPS adalah pelajaran menjenuhkan. Selama ini evaluasi yang dilakukan guru terhadap pembelajaran IPS hanya sebatas pemberian nilai yang diperoleh dari tes akhir setelah proses pembelajaran, tanpa memperhatikan proses pembelajaran siswa.

Permasalahan yang ditemukan dalam pembelajaran IPS adalah kurangnya kemauan guru mengembangkan metode pembelajaran. Metode yang biasa digunakan dalam pembelajaran IPS bersifat konvensional, sehingga proses pembelajaran berpusat pada guru. Padahal yang diharapkan adalah pembelajaran menggunakan metode yang melibatkan siswa aktif secara menyeluruh, fisik maupun mental. Dengan demikian potensi yang dimiliki siswa dapat berkembang sehingga dapat meningkatkan hasil belajar siswa.

Hasil pretes menunjukkan siswa dari jumlah siswa 31 orang memperoleh nilai rata-rata sebesar 74. Artinya taraf hasil belajar siswa kurang dari KKM yaitu sebesar 80 . 


\section{Hasil Penelitian Siklus I \\ Perencanaan Tindakan Penelitian}

Pada tahap perencanaan tindakan penelitian dilakukan kegiatan penyusunan berbagai instrumen pembelajaran. Tiga instrumen pembelajaran adalah rencana pembelajaran, instrumen observasi kegiatan guru dan instrumen observasi kegiatan siswa.

Selain penyusunan instrumen pembelajaran, dilakukan pula persiapan berbagai sarana penunjang, seperti penataan ruang kelas, pengorganisasian siswa dan kesiapan peneliti dan observer. Hal ini dimaksudkan agar proses pelaksanaan penelitian berjalan lancar sesuai dengan tujuan penelitian.

\section{Pelaksanan Pembelajaran}

Langkah-langkah pelaksanaan pembelajaran tindakan pertama meliputi mengungkap pengetahuan awal siswa dengan tes awal (pretes), mengungkap pengalaman siswa dalam menyelesaikan soal materi Letak Geografis dan Koordinat Negara ASEAN dengan penggunaan metode resitasi, mengkondisikan siswa untuk belajar, membagikan LKS dan alat/media pembelajaran, memberikan petunjuk kepada siswa cara mengerjakan LKS dan menggunakan alat/media pembelajaran serta memberikan kesempatan belajar kepada siswa, siswa mengerjakan LKS secara berkelompok, guru mengamati kegiatan siswa selama pembelajaran, guru memberikan kesempatan kepada siswa untuk bertanya/menjawab pertanyaan, siswa melakukan diskusi kelompok, siswa dan guru menyimpulkan hasil diskusi kelas. Akhir pelaksanaan tindakan dilakukan postes untuk mengukur hasil belajar siswa.

\section{Data Hasil Observasi}

\section{Analisis Data Rencana Pembelajaran Tindakan Pertama}

Analisis data rencana pembelajaran tindakan pertama bersumber pada hasil observasi rencana pembelajaran. Terdapat lima aspek yang menjadi sasaran observasi, yakni aspek kurikulum, bahan pembelajaran, strategi pembelajaran, media dan sumber belajar, serta aspek evaluasi. Dari empat indikator yang terdapat pada aspek kurikulum terdapat dua indikator yang menunjukan skor 1,00 yakni indikator mencantumkan identitas (nama sekolah, mata pelajaran, kelas/semester, dan waktu) dan mencantumkan standar kompetensi. Dua aspek lain, yakni indikator mencantumkan kompetensi dasar dan pemilihan indikator sesuai dengan kebutuhan setiap pembelajaran mendapat skor 0,75 . Skor rata-rata aspek kurikulum sebesar 3,5 dengan kualitas baik sekali.

Dari empat indikator pada aspek bahan pembelajaran, terdapat dua indikator yang mendapat skor 1,00, yakni indikator mencantumkan materi Letak Geografis dan Koordinat Negara ASEAN, bahan pembelajaran disusun secara sistematis, logis dan proporsional. Dua indikator yang mendapat skor 0,75 adalah indikator materi Letak Geografis dan Koordinat Negara ASEAN sesuai dengan tingkat perkembangan psikis dan fisik siswa dan materi pembelajaran untuk mengungkap pemahaman siswa. Aspek bahan pembelajaran mendapat skor 3,50 atau dengan kriteria baik sekali secara kualitas.

Pada aspek strategi pembelajaran hanya satu indikator yang mendapat skor 0,50 , yakni indikator merancang dengan tepat penataan kelas dan pengorganisasian siswa. Tiga indikator lain mendapat skor 1,00. Aspek strategi mendapat nilai 3,50 atau dengan kriteria baik sekali.

Aspek keempat dari hasil observasi rencana pembelajaran adalah aspek media dan sumber belajar. Terdapat dua indikator yang mendapat skor 0,75 , yakni indikator mencantumkan alat, media dan sumber belajar sesuai dengan kompetensi dasar, indikator dan hasil belajar dan disesuaikan dengan kondisi kelas, sekolah atau lingkungan sekitar. Sementara dua indikator yang mendapat skor 1,00 adalah indikator mempertimbangkan kepraktisan, kemudahan dan inovatif dan penggunaan metode dan sumber belajar berdasarkan atas metode resitasi. Aspek media dan sumber belajar mendapat skor 3,50 atau nilai kualitatif baik sekali. 
Aspek terakhir adalah aspek evaluasi mendapat skor 3,25 atau dengan nlai kualitatif baik. Dua indikator mendapat skor 1,00 yakni indikator mencantumkan bentuk dan jenis penilaian serta prosedur penilaian dan skala penilaian dan indikator penggunaan alat evaluasi relevan dengan hasil belajar. Secara keseluruhan rencana pembelajaran mendapat skor ratarata 3,45 atau $86,25 \%$. Sedangkan jumlah skor dari rencana pembelajaran sebesar 17,25 atau $86,25 \%$.

\section{Analisis Data Aktivitas Guru dalam Pembelajaran}

Observasi aktivitas guru pada pembelajaran mencakup 3 aspek yakni aktivitas membuka pelajaran, proses pembelajaran dan menutup pelajaran. Berdasarkan data nilai hasil pengamatan kerja guru dalam melaksanakan pembelajaran dengan penggunaan metode resitasi tindakan pertama diperoleh nilai rata-rata sebesar 3,06 dengan kriteria baik. Hal ini menunjukan bahwa aspek-aspek yang dijadikan standar penilaian dalam penggunaan metode resitasi jawab ini sudah dicapai oleh guru, namun masih belum optimal.

Dari hasil observasi terhadap aktivitas guru dalam pembelajaran tindakan pertama, diperoleh data jumlah skor sebesar 36,75 atau $76,5 \%$. Skor rata-rata aktivitas guru dalam pembelajaran adalah 3,06 atau $76,5 \%$.

\section{Analisis Data Aktivitas Siswa pada Pembelajaran}

Hasil pengamatan observer terhadap aktivitas siswa dalam pembelajaran tindakan pertama menunjukkan bahwa jika pada hasil observasi aktivitas guru terdapat beberapa indikator yang mendapat skor 0,50, maka hasil pengamatan aktivitas siswa dalam pembelajaran tindakan pertama menunjukan hanya dua indikator dari aspek kejujuran dan keterbukaan yang mendapat skor 0,50. Dari 16 indikator yang tersebar pada empat aspek pengamatan, rata-rata mendapat skor 0,75 dan 1,00. Sehingga hasil rata-rata aktivitas siswa mendapat skor rata-rata 3,12 atau jika diprosentasikan sebesar $78 \%$, dan jumlah skor 12,5 atau jika diprosentasikan sebesar $78,12 \%$.

\section{Analisis Data Postes Pembelajaran Tindakan Pertama}

Proses data nilai postes atau nilai hasil akhir siswa (postes) setelah dilakukan pembelajaran dengan menggunakan metode resitasi. Berdasarkan data nilai postes rata-rata nilai belajar siswa adalah 79 , dengan demikian hasil belajar siswa dikategorikan cukup. Dengan demikian, dilihat dari hasil postes, secara umum terdapat peningkatan dengan selisih nilai pretes dan postes sebesar $5 \%$. Nilai rata-rata postes pembelajaran tindakan pertama sebesar 79 .

\section{Refleksi Tindakan Pembelajaran Pertama}

Refleksi didasarkan pada hasil analisis tindakan pembelajaran pertama, baik hasil analisis secara pembelajaran, hasil analisis aktivitas guru dan siswa serta analisis hasil belajar siswa. Dari rencana pembelajaran dapat terlihat pengaturan waktu kegiatan pembelajaran. Hal ini dibuktikan dari rendahnya perolehan nilai pengaturan waktu yang hanya mendapat 0,50.

Secara umum aktivitas guru pada pelaksanaan tindakan pertama sudah baik, namun ada beberapa hal yang perlu dipertimbangkan untuk diperbaiki pada pelaksanaan tindakan kedua. Beberapa hal yang perlu mendapat perhatian adalah mengenai kemampuan bertanya dengan menerapkan teknik-teknik bertanya, pengorganisasian waktu dalam proses pembelajaran, memberi penjelasan materi dengan contoh, dan pemberian tindak lanjut pembelajaran.

Dari uraian tentang hasil observasi terhadap kinerja siswa, dapat diuraikan beberapa kegiatan yang telah dilaksanakan, antara lain siswa : memperhatikan penjelasan guru dan bekerjasama dalam kegiatan kelompok. Walaupun secara umum aktivitas siswa telah memenuhi tuntutan sesuai indikator, namun siswa belum menunjukan perilaku jujur dan terbuka pada waktu melaksanakan kegiatan kerja kelompok.

Kekurangan-kekurangan yang ditemukan pada pembelajaran tindakan pertama didiskusikan bersama-sama antar peneliti dan observer, karena hasil dan analisis refleksi 
tindakan pembelajaran ini akan menjadi bahan refleksi bagi peneliti untuk merancang dan melaksanakan tindakan pembelajaran kedua.

\section{Hasil Penelitian Siklus II}

Berdasarkan hasil refleksi tindakan siklus I maka ada perbaikan pada tahap perencanaan, pelaksanaan dan peningkatan hasil belajar siswa dalam Letak Geografis dan Koordinat Negara ASEAN. Pemaparan pelaksanaan siklus II juga dideskripsikan berdasarkan perencanaan, pelaksanaan, observasi dan refleksi.

\section{Perencanaan Tindakan Penelitian}

Rencana perbaikan pembelajaran yang dirumuskan dalam kegiatan perencanaan dalam bentuk Rencana Pelaksanaan Pembelajaran (RPP) yang dibuat pada siklus I. Perbaikan yang dilakukan dalam rencana pembelajaran sesuai refleksi siklus I yaitu pada penggunaan atau pengalokasian waktu dan perbaikan pada ukuran gambar yang menjadi alat bantu pembelajaran.

Pada siklus II tujuan pembelajaran selain siswa dapat menjelaskan perlunya Letak Geografis dan Koordinat Negara ASEAN dengan menggunakan media visual, siswa juga diharapkan dapat menyebutkan Letak Geografis dan Koordinat Negara ASEAN di daerah tempat tinggalnya dengan menggunakan media visual. Langkah-langkah kegiatan pembelajaran yang direncanakan pada siklus II tidak berbeda dengan kegiatan siklus I yaitu meliputi kegiatan awal, kegiatan inti dan kegiatan akhir.

\section{Pelaksanan Pembelajaran Tindakan Kedua}

Peneliti melakukan proses pembelajaran seperti biasa dan peneliti bertindak sebagai pengajar. Peneliti dibantu oleh seorang guru mitra yang bertindak sebagai observer. Guru mengawali pembelajaran dengan mengucapkan salam, lalu guru mengabsen siswa. Guru menyampaikan tujuan pembelajaran yang akan disampaikan. Sebelum menjelaskan materi yang akan disampaikan, guru terlebih dahulu membahas PR yang diberikan pada pertemuan sebelumnya dan memberikan penilaian. Setelah itu guru mulai menjelaskan materi pelajaran menggunakan metode resitasi. Guru menjelaskan materi tentang Letak Geografis dan Koordinat Negara ASEAN.

\section{Data Hasil Observasi Tindakan Kedua}

Berdasarkan perencanaan dalam bentuk Rencana Pelaksanaan Pembelajaran (RPP), pelaksanaan pembelajaran, serta hasil belajar siswa dalam berdiskusi, hasilnya diuraikan dalam bentuk format observasi. Format-format tersebut adalah sebagai berikut :

\section{Analisis Data Rencana Pembelajaran Tindakan Kedua}

Observasi terhadap perencanaan (Rencana Pelaksanaan Pembelajaran) dengan hasil observasi data rencana pembelajaran IPS Siklus II, berdasarkan data nilai hasil pengamatan terhadap rencana pembelajaran tindakan kedua diperoleh skor rata-rata 3,12 atau $78,12 \%$. Aspek yang dijadikan standar penilaian dalam meningkatkan hasil belajar siswa tentang penggunaan metode resitasi pada pembelajaran IPS tentang Letak Geografis dan Koordinat Negara ASEAN sudah dicapai oleh guru. Meningkatnya skor dan nilai rata-rata rencana pembelajaran tindakan kedua ini, diharapkan dapat meningkatkan hasil belajar siswa setelah kegiatan pembelajaran selanjutnya.

\section{Analisis Data Aktivitas Guru dalam Tindakan Pembelajaran Kedua}

Hasil pengamatan observasi terhadap aktivitas guru dalam pembelajaran IPS siklus II diperoleh skor rata-rata sebesar 3,06 atau $76,56 \%$. Artinya bahwa aspek-aspek yang dijadikan standar penilaian dalam meningkatkan hasil belajar siswa tentang penggunaan metode resitasi pada pembelajaran IPS tentang Letak Geografis dan Koordinat Negara ASEAN yang dilaksanakan oleh guru sudah tercapai secara optimal. 


\section{Analisis Data Aktivitas Siswa pada Pembelajaran Tindakan Kedua}

Hasil observasi aktivitas siswa dalam pembelajaran IPS Siklus II berdasarkan data hasil kerja siswa dalam melaksanakan pembelajaran IPS tentang penggunaan metode resitasi untuk meningkatkan hasil belajar siswa tentang Letak Geografis dan Koordinat Negara ASEAN pada tindakan kedua diperoleh nilai rata-rata sebesar 3 atau 75\%. Artinya bahwa aspek-aspek yang dijadikan standar penilaian dalam pembelajaran IPS untuk meningkatkan hasil belajar siswa tentang penggunaan metode resitasi tentang Letak Geografis dan Koordinat Negara ASEAN sudah dicapai oleh guru dan hasilnya optimal.

\section{Analisis Data Postes Pembelajaran Tindakan Kedua}

Hasil belajar siswa dalam pembelajaran IPS tentang penggunaan metode resitasi untuk meningkatkan hasil belajar siswa tentang Letak Geografis dan Koordinat Negara ASEAN, setelah dilaksanakan maka diperoleh hasil belajar siswa rata-rata nilai hasil belajar siswa sebesar 84 . Dengan demikian, hasil belajar siswa dapat dikategorikan sangat baik dan telah memenuhi KKM yang ditetapkan yaitu 80 .

\section{Refleksi Pembelajaran Siklus II}

Hasil observasi data rencana pembelajaran IPS Siklus II, berdasarkan data nilai hasil pengamatan terhadap rencana pembelajaran tindakan kedua diperoleh skor rata-rata 3,12 atau $78,12 \%$. Hasil pengamatan kerja guru tentang penggunaan metode resitasi untuk meningkatkan hasil belajar siswa pada pembelajaran IPS tentang Letak Geografis dan Koordinat Negara ASEAN pada tindakan kedua diperoleh skor rata-rata sebesar 3,06 atau 76,56\%. Artinya bahwa aspekaspek yang dijadikan standar penilaian dalam penggunaan metode resitasi untuk meningkatkan hasil belajar siswa pada pembelajaran IPS tentang Letak Geografis dan Koordinat Negara ASEAN sudah dicapai oleh guru dan hasilnya optimal.

Aktivitas siswa dalam penggunaan metode resitasi untuk meningkatkan hasil belajar siswa pada pembelajaran IPS tentang Letak Geografis dan Koordinat Negara ASEAN pada tindakan kedua diperoleh nilai rata-rata sebesar 3 atau $75 \%$. Artinya bahwa aspek-aspek yang dijadikan standar penilaian dalam pembelajaran IPS untuk meningkatkan hasil belajar siswa tentang penggunaan metode resitasi tentang Letak Geografis dan Koordinat Negara ASEAN sudah dicapai oleh guru dan hasilnya optimal.

Berdasarkan hasil observasi dan temuan data hasil belajar siswa tentang penggunaan metode resitasi pada pembelajaran IPS tentang Letak Geografis dan Koordinat Negara ASEAN pada siklus II ternyata sudah mencapai target dengan rata-rata 84 atau $84 \%$. Dengan demikian, tindakan penelitian pada siklus II telah memenuhi target sebesar 80 , sehingga tidak diperlukan perbaikan pembelajaran pada siklus selanjutnya.

\section{Pembahasan Hasil Penelitian}

\section{Perencanaan Tindakan Penelitian}

Salah satu tahap kegiatan Penelitian Tindakan Kelas adalah tahap refleksi terhadap kegiatan yang telah dilakukan pada tindakan sebelumnya, untuk kemudian hasil refleksi tersebut dijadikan bahan pertimbangan pelaksanaan tindakan selanjutnya. Pada tahap refleksi diungkap beberapa aspek yang telah memenuhi standar yang diharapkan dan aspek-aspek yang belum memenuhi standar yang telah ditentukan.

Rencana Pelaksanaan Pembelajaran yang disusun untuk pelaksanaan tindakan pertama sebagian besar telah memenuhi standar yang diharapkan, seperti diuraikan pada bagian analisis data hasil penelitian. Standar tersebut didasarkan pada perolehan skor pada tiap indikator yakni mendapat skor maksimal 1,00 atau dengan perolehan nilai akhir untuk tiap aspek mendapat kriteria sangat baik.

Aspek-aspek yang mendapat nilai baik sekali adalah aspek kurikulum, bahan pembelajaran, strategi pembelajaran, dan media/sumber belajar. Namun demikian aspek-aspek dimaksud belum memenuhi standar maksimal secara keseluruhan. Artinya nilai tiap-tiap aspek belum menunjukan nilai maksimal, yakni nilai 4,00. Sedangkan pada rencana pembelajaran tindakan kedua aspek- 
aspek tersebut mendapat nilai maksimal 4,00, dan secara kualitatif mendapat kriteria sama yakni kriteria sangat baik.

Satu aspek yang belum memenuhi standar yang diharapkan adalah aspek evaluasi. Pada rencana pembelajaran pertama aspek ini mendapat nilai 3,25 atau kriteria baik. Berbeda dengan nilai yang diperoleh pada rencana pembelajaran tindakan kedua mendapat nilai maksimal atau dengan kriteria sangat baik.

Sehubungan dengan uraian yang telah dipaparkan dapat dijelaskan bahwa rencana pembelajaran terlihat adanya perubahan ke arah penyempurnaan. Hal ini di buktikan dengan peningkatan prosentase nilai rencana pembelajaran. Rencana pembelajaran tindakan pertama mendapat skor $86,7 \%$, sedangkan rencana pembelajaran kedua mendapat skor $100 \%$. Hal ini merupakan salah satu faktor meningkatnya hasil belajar siswa pada pembelajaran dengan metode resitasi.

\section{Pelaksanaan Tindakan}

Pembahasan pelaksanaan tindakan difokuskan pada perbandingan aktivitas guru pada tindakan pertama dengan aktivitas guru pada tindakan kedua, serta perbandingan aktivitas siswa pada tindakan pertama dengan aktivitas pada tindakan kedua.

Nilai rata-rata aktivitas guru pada tindakan kedua mengalami peningkatan jika dibandingkan dengan perolehan nilai pada tindakan pertama. Pada tindakan pertama nilai rata-rata aktivitas guru sebesar 3,06, sedangkan pada tindakan kedua sebesar 3,50.

Walaupun secara umum aktivitas guru mengalami peningkatan, namun ada beberapa hal yang perlu mendapat perhatian karena skor pada indikator tertentu menunjukan nilai 0,50 , baik pada tindakan pertama maupun pada tindakan kedua. Dari aspek penguasaan materi, menunjukan bahwa aktivitas menjelaskan materi dan memberi contoh pada saat proses pembelajaran berlangsung mendapat nilai sama, yakni 0,50. Pada bagian akhir pembelajaran, yakni aktivitas guru dalam memberi tindak lanjut pemahaman kepada siswa. Pada aspek ini upaya memberi pekerjaan rumah mendapat skor 0,50 baik pada tindakan pertama maupun pada tindakan kedua.

Dilihat dari perbandingan rata-rata nilai aktivitas siswa pada tindakan pertama dan kedua, menunjukan adanya peningkatan aktivitas. Bila pada tindakan pertama nilai rata-rata aktivitas siswa sebesar 3,12, maka pada tindakan pembelajaran kedua nilai rata-rata aktivitas siswa mendapat nilai 3,50 .

Dari keempat aspek yang menjadi sasaran observasi, terdapat tiga aspek yang menunjukan kriteria sangat baik, baik pada tindakan pertama maupun pada tindakan kedua. Ketiga aspek tersebut adalah : aspek memperhatikan penjelasan guru pada tindakan pertama mendapat nilai 3,25 , aspek kerjasama dalam mengerjakan LKS pada tindakan pertama dan tindakan kedua mendapat nilai 3,50 , serta aspek kemampuan memecahkan masalah, pada tindakan pertama mendapat nilai 3,25 dan pada tindakan kedua 3,75.

Satu aspek yang memiliki perbedaan nilai mencolok adalah aspek kejujuran dan keterbukaan. Pada tindakan pertama mendapat nilai rata-rata 2,50 dan meningkat secara drastis pada tindakan kedua, yakni mendapat nilai rata-rata 3,50.

\section{Hasil Belajar Siswa}

Hasil belajar siswa secara keseluruhan dapat diuraikan dengan membandingkan nilai pos tes pada tindakan pertama dengan nilai postes pada tindakan kedua. Dari 31 orang siswa, ternyata nilai postes tindakan pertama dengan nilai rata-rata 79 , sedangkan nilai postes tindakan kedua dengan nilai rata-rata 84.

Rendahnya nilai rata-rata siswa pada hasil belajar tindakan pertama diakibatkan oleh banyaknya siswa yang mendapat nilai 70 . Hal ini berbeda dengan perolehan nilai hasil belajar siswa pada tindakan kedua. Perbedaan nilai rata-rata tindakan pertama dengan nilai rata-rata tindakan kedua adalah sebesar $5 \%$. Nilai rata-rata siswa pada hasil belajar tindakan pertama sebesar 79 , sedangkan nilai rata-rata hasil belajar pada tindakan kedua sebesar 84. Jika dianalisa perbedaan nilai antara tindakan pertama dan kedua menunjukan adanya perubahan yang lebih baik. 
Gambaran umum data hasil penelitian menyangkut aspek rencana pembelajaran, aktivitas guru dan siswa serta nilai postes siswa pada tindakan pertama dan tindakan kedua. Data-data hasil penelitian tindakan pertama dan tindakan kedua selengkapnya dapat dilihat pada Tabel 2, tentang perbandingan hasil pelaksanaan tindakan I dengan tindakan II.

Tabel 2.

Perbandingan Hasil Pelaksanaan Siklus I dengan Siklus II

\begin{tabular}{|c|c|c|}
\hline Aspek Tindakan & Siklus I & Siklus II \\
\hline Rencana Pembelajaran & $\begin{array}{l}\text { Rencana pembelajaran tindakan } \\
\text { pertama mendapat skor rata-rata } 3,35 \\
\text { atau } 83,75 \%\end{array}$ & $\begin{array}{l}\text { Rencana pembelajaran tindakan kedua } \\
\text { memperoleh skor rata-rata } 4,00 \text { atau } \\
100 \%\end{array}$ \\
\hline Aktivitas Guru & $\begin{array}{l}\text { Aktivitas guru dalam pembelajaran } \\
\text { tindakan pertama memperoleh skor } \\
\text { rata-rata } 3,06 \text { atau } 76,5 \%\end{array}$ & $\begin{array}{l}\text { Aktivitas guru dalam pembelajaran } \\
\text { tindakan kedua memperoleh skor rata- } \\
\text { rata sebesar } 3,50 \text { atau } 87,5 \%\end{array}$ \\
\hline Aktivitas siswa & $\begin{array}{l}\text { Aktivitas siswa dalam pembelajaran } \\
\text { tindakan pertama mendapat skor rata- } \\
\text { rata } 3,12 \text { atau } 78 \%\end{array}$ & $\begin{array}{l}\text { Aktivitas siswa dalam pembelajaran } \\
\text { tindakan kedua memperoleh skor rata- } \\
\text { rata sebesar } 3,62 \text { atau } 90,55 \%\end{array}$ \\
\hline Nilai Postes & $\begin{array}{l}\text { Nilai postes pembelajaran tindakan } \\
\text { pertama, rata-rata } 79\end{array}$ & $\begin{array}{l}\text { Nilai postes pembelajaran tindakan } \\
\text { kedua rata-rata } 84\end{array}$ \\
\hline
\end{tabular}

Peningkatan-peningkatan pada setiap aspek tindakan menunjukkan bahwa penggunaan metode resitasi dapat meningkatkan hasil belajar siswa dalam pembelajaran IPS tentang Letak Geografis dan Koordinat Negara ASEAN.

\section{KESIMPULAN}

Kesimpulan yang diperoleh berdasarkan pembahasan hasil penelitian tentang penggunaan metode resitasi untuk meningkatkan hasil belajar siswa pada pembelajaran IPS tentang Letak Geografis dan Koordinat Negara ASEAN di Kelas VIII-G SMPN 6 Tasikmalaya, adalah Rencana Pelaksanaan Pembelajaran tindakan pertama mendapat mendapat skor rata-rata 3,35 atau 83,75\%. Sedangkan rencana pembelajaran tindakan kedua memperolah skor rata-rata 4,00 atau $100 \%$. Hal ini berarti terdapat peningkatan kinerja guru dalam menyusun Rencana Pelaksanaan Pembelajaran IPS berpengaruh terhadap peningkatkan hasil belajar siswa tentang Letak Geografis dan Koordinat Negara ASEAN melalui penggunaan metode resitasi di Kelas VIII-G SMPN 6 Tasikmalaya Kabupaten Tasikmalaya.

Proses pembelajaran memperoleh skor rata-rata aktivitas guru pada tindakan pertama adalah 3,06 atau $76,5 \%$. Tindakan kedua mendapat skor rata-rata 3,50 atau $87,5 \%$. Untuk aktivitas siswa pada tindakan kedua siswa mendapat skor rata-rata 3,12 atau 78\%. Pada Tindakan kedua mendapat skor rata-rata 3,62 atau 90,55\%. Sesuai dengan hasil tersebut ternyata aktivitas guru dan siswa dalam pelaksanaan pembelajaran IPS mengalami peningkatan. Hal ini berarti bahwa hasil belajar siswa tentang materi Letak Geografis dan Koordinat Negara ASEAN melalui metode resitasi dengan metode resitasi berpengaruh terhadap penguasaan siswa

Hasil belajar siswa pada tindakan pertama nilai rata-rata sebesar 79 , pada tindakan kedua sebesar 84. Hal ini dapat diartikan bahwa pembelajaran IPS melalui metode resitasi, selain berpengaruh terhadap rencana dan pelaksanaan pembelajaran, juga berpengaruh terhadap peningkatkan hasil belajar siswa tentang materi Letak Geografis dan Koordinat Negara ASEAN di kelas VIII-G SMPN 6 Tasikmalaya Kabupaten Tasikmalaya setelah melaksanakan kegiatan pembelajaran IPS dalam upaya meningkatkan hasil belajar siswa tentang Letak Geografis dan Koordinat Negara ASEAN melalui metode resitasi.

Saran dari penelitian adalah bagi sekolah, hasil penelitian ini diharapkan dapat dijadikan bahan pertimbangan untuk memberikan keleluasaan pada guru dalam rangka merancang rencana pembelajaran dengan menggunakan berbagai pendekatan pembelajaran khususnya melalui metode resitasi. Bagi guru, hasil penelitian ini diharapkan dapat dijadikan bahan pemikiran untuk mempertimbangkan penggunaan berbagai pendekatan pembelajaran khususnya penggunaan metode resitasi dalam merencanakan dan melaksanakan pembelajaran, khususnya pada mata 
pelajaran ekonomi. Bagi siswa, dengan penggunaan metode resitasi pada pembelajaran IPS diharapkan dapat memberi motivasi dan meningkatkan aktivitas siswa dalam mengikuti proses pembelajaran, khususnya pembelajaran ekonomi.

\section{REKOMENDASI}

Pada penelitian selanjutnya dapat menggunakan metode lain selain metode resitasi dan juga pada pelajaran lain selain pelajaran IPS.

\section{UCAPAN TERIMAKASIH}

Peneliti mengucapkan terima kasih kepada siswa kelas VIII-G SMPN 6 Tasikmalaya yang telah mendukung terhadap pelaksanaan penelitian ini.

\section{DAFTAR PUSTAKA}

Ahmadi, A. (2004). Psikologi Belajar. Bandung : Pustaka Setia.

Alipandie, I. (2001). Didaktik Metodik Pendidikan. Surabaya: Penerbit Usaha Nasional.

Alipandie, I. (2004). Metode Resitasi (Penugasan) dalam Pembelajaran. Jakarta : Bina Mulya.

BSNP. (2006). Kurikulum Tingkat Satuan Pendidikan (KTSP) Ekonomi. Jakarta : Dinas Pendidikan dan Kebudayaan.

Harmawati. (1993). Penugasan dalam Pembelajaran. Jakarta : Pustaka Setia.

Kasbolah, K (1999). Penelitian Tindakan Kelas. Malang : Depdikbud Proyek PGSD.

Rostiyah. (2001). Metode Penugasan dalam Proses Belajar Mengajar. Jakarta : Persada Press.

Rusyan, T. (1989). Pendidikan Masa Kini dan Mendatang, Jakarta : Bina Mulya.

Sudirman. (2002). Ilmu Pendidikan : Kurikulum Program Pengajaran, Efek Intuksional Metode Mengajar, Media Pendidikan dan Evaluasi Hasil Belajar. Bandung : Remaja Rosda Karya.

Sudjana, N. (1989). Dasar-Dasar Proses Belajar Mengajar. Bandung : Sinar Baru.

Slameto. (1991). Belajar dan Faktor-faktor yang Mempengaruhinya. Bandung : Rineka.

Slameto. (2001). Proses Belajar Mengajar dalam Sistem Kredit (SKS). Jakarta : Penerbit Bumi Aksara.

Wahab, A. A. (2007). Metode dan Model-model Mengajar IImu Pengetahuan Sosial (IPS). Bandung : Alfabeta. 